\title{
Ecotourism Management Structuring At The Salak Mountain II Resort, Halimun Salak National Park
}

\author{
Andrianto Kusumoarto ${ }^{1)}$, Ryan Hidayat ${ }^{1)}$, Siti Jubei ${ }^{2)}$, Atie Ernawati1) \\ ${ }^{1)}$ Study Program of Architecture, Fakultas of Technic and Computer Science, Indraprasta \\ PGRI University \\ ${ }^{2)}$ Study Program of Indonesian Language Eduacation, Faculty of Language and Literature, \\ Indraprasta PGRI University
}

Corresponding author : andrianto.kusumoarto@unindra.ac.id; andri_anto72@yahoo.com

\begin{abstract}
ARTICLE INFO
Received

28 January 2019

Accepted

07 September 2019

Available online

30 September 2019
\end{abstract}

\begin{abstract}
The Salak Mountain II Resort Area, Halimun Salak National Park has several ecotourism objects that have a good ecotourist attraction. In the Salak Mountain II Resort area, there are several actors who have a role in management, where there are several obstacles faced during the course of the activity. The objectives in this study are 1) identifying elements in the management structure variables; 2) analyze the goals variable of ecotourism development, needs variable of ecotourism development, activity programs variable of ecotourism development, obstacles variable of ecotourism development, and actors variable of ecotourism development; 3) making the model of ecotourism management structuring. The method used in this study is descriptive qualitative with Interpretive Structural Modeling (ISM) analysis. The results of the study shown that the desired goals in managing the area are the conservation of natural resources and their ecosystems, and providing education to the community about environmental management. The desired need in area management is the existence of ecotourism legality. Some of the desired program activities in regional development and management are agrotourism, local cultural and artistic attractions, ecotourism, and natural recreation. Some obstacles in the development and management of the area are the limited human resources that have knowledge, skills in managing ecotourism areas and changes in the status of the utilization zone to the ecotourism zone. Salak Mountain II Resort Office, Koperasi Khalifah, Village-Owned Business Entity are actors who have very strong driving factors and function as variable linkage. Each element in the variable has different strengths as a driver and dependency.
\end{abstract}

Keywords : Interpretive Structural Modeling, Ecotourism Management, Landscape Management, The Salak Mountain II Resort, Halimun Salak National Park 


\section{INTRODUCTION}

\section{Background}

The Salak Mountain II Resort Area, Halimun Salak National Park (HSNP) is a natural resource conservation area that has very interesting ecotourism objects. This area has attractive landscape potential as an ecotourism area (Kusumoarto, Gunawan, and Nurazizah, 2017). There are 11 (eleven) ecotourism areas managed by the Salak MountainII Resort Office, HSNP. The ecotourism objects are Cigamea Waterfall Area, Kondang Waterfall Area, Hot Spring Area, Ngumpet Waterfall Area, Seribu Waterfall Area, Pangeran Waterfall Area, Muara Waterfall Area, Cihurang Waterfall Area, Ratu Crater Area, Camping Ground Area, and Alami Waterfall Area (Kusumoarto and Ramadhan, 2016). Tourist visits to this region in 2016 were recorded at 17,969 people. The highest number of visits to hot springs area was recorded at 4,668 people and visits to the camping ground area were recorded to be the smallest of 365 people. Ecotourism objects that have potential visits based on the perceptions and desires of visitors are Cigamea Waterfall Area, Kondang Waterfall Area, Hot Spring Area, and Ngumpet Waterfall Area (Jubei, Kusumoarto, Ernawati, 2017). Ecotourism objects that have a level of visits with more than 1,000 visitors in 2018 are Hot Springs Area (4,668 people), Kondang Waterfall Area (3,824 people), Cigamea Waterfall Area (3288 people), Ngumpet Waterfall Area (1,328 people), Seribu Waterfall Area (1,328 people), and Pangeran Waterfall Area (1,072 people).

As a natural resource conservation area, Salak Mountain II Resort Area, HSNP has good natural beauty, has biodiversity, cultural uniqueness, and easy accesibility to reach it (Kusumoarto and Ramadhan, 2016). The existence of natural resource potential and a number of constraints faced resulted in ecotourism objects in the region having different carrying capacity (Kusumoarto and Ernawati, 2018). Based on the potential and existing problems as expressed by Ernawati, Kusumoarto, and Jubei (2018) it is necessary to design and manage strategies as an effort to maintain the sustainability of the region as an ecotourism area. This area is part of the national park that has a distinctive character, so that management activities carried out need to pay attention to the landscape character. Kusumoarto, et al. (2017), stated that the natural resource conservation area as a protected area has a good of landscape character for ecotourism. 
Management of the Salak Mountain II Resort Area, HSNP is required by the Halimun Salak National Park Office (HSNPO), Ministry of Environment and Forestry, Republic of Indonesia to carry out activities to protect the area's ecosystems, prevent damage that occurs in the area, prevent land conversion, protect ecotourism activities carried out by visitors, arrange and protect ecotourism object facilities, protect visual quality of natural resources, and development and protection of accessibility. In conducting good management as towards the sustainability, it is necessary to structure the management of the Salak Mountain II Resort Area, HSNP. Structuring as the main objective of this research is based on the perceptions of experts so that it can be seen the institutional structure model of the management of the Salak Mountain II Resort Area, HSNP.

Expert perceptions are included in the decision-making components of an individual person consisting of perception, attitude, value, preference, and satisfaction, where all components influence each other in taking decision (Porteous 1977). The perceptions of experts have a close relationship with their preferences so it is important to know and study perceptions and preferences in the framework of developing and managing http://ojs.unud.ac.id/index.php/eot an area (Porteous 1977). Preference is the tendency to choose something that is preferred over others. According to Porteous (1977), studies of individual behavior can be used by environmentalists and designers to assess the desires of users (users) of a planned object.

\section{Research Objectives}

The objectives in this study are 1) identifying elements in the management structure variables; 2) analyze the goals variable of ecotourism development, needs variable of ecotourism development, activity programs variable of ecotourism development, obstacles variable of ecotourism development, and actors variable of ecotourism development; 3) making the model of ecotourism management structuring.

\section{LITERATURE REVIEW}

Ecotourism is a tourism development model that respects natural rules by implementing integrated development and conservation programs between efforts to conserve natural resources with sustainable community economic development (Choy 1997; Fandelli 2000; Buchsbaum 2004; Gunn 1994; Avenzora 2008). Ecotourism activities are carried out in natural areas to 
get new experiences in carrying out their trips, usually carried out by visitors with a small amount (Gunn, 1994). Sustainable ecotourism is inspired by the concept of sustainable development. The concepts for achieving sustainable tourism destinations require ecological integration as an effort to achieve the vision of sustainable development.

ISM analysis techniques are used to form alternative policies in the future. In practice this method is carried out in two stages. The first stage identified key stakeholders who were the most influential in developing ecotourism. The second stage, determines a number of key factors obtained from need analysis that are reviewed through expert discussion and based on theory in the ecotourism system.

Preliminary information of stakeholders using the snawball method where stakeholders recommend other stakeholders as respondents (Dunn, 2003). After identifying and mapping stakeholders, further identification of the needs and aspirations of each stakeholder is carried out according to the priority scale (Storey, 1999). The needs and aspirations of each stakeholder are then discussed together with experts to get key stakeholders. Determination of experts is based on considerations and criteria: 1) existence, affordability, and willingness to be interviewed; 2) reputation, position, and http://ojs.unud.ac.id/index.php/eot credibility as experts; 3) personal experience (Eriyatno and Sofyan, 2007). The main activities carried out are as follows: 1) identifying and mapping key stakeholders who are in compliance with regional management and evaluating the role and path capacity that can be played, 2) observing interests, conflicts, and the role of stakeholders in relations with resources, 3) identifying relationship between stakeholders to be built in an effort to produce an appropriate policy; 4) grouping stakeholders according to their interests and influence, 5) identifying existing institutions related to research, 6) identifying constraints related to ecotourism management.

\section{METHODOLOGY}

This research was conducted in the Salak Mountain II Resort Area, HSNP. The study was conducted for 6 months, starting from June to November 2018. The method used in this study is descriptive qualitative with Interpretive Structural Modeling (ISM) analysis tools, with related elements, namely: 1) objectives to be achieved in managing the area , 2) needs in managing the area, 3) program activities needed, 4) constraints that need to be addressed, and 5) actors who play a role in managing ecotourism areas. 
The stage of ISM analysis is the determination of contextual relationships which are then converted into mathematical relationships $(\mathrm{Rm})$. Relations between elements fulfill reflexive and transitive properties (Machfud, 2001). In the process of transforming contextual relations (Matrix Structural Self-Interaction) into a form of mathematical relationship in the form of a Reachability matrix with complete rules can be seen in Table 1 .

Table 1. Transformation of the form of contextual relationships between elements into forms of mathematical relationships

\begin{tabular}{cc}
\hline Form of & Form of \\
Contextual & Mathematical \\
Relations & Relations Between \\
Between & Elements $\mathrm{i}$ and $\mathrm{j}$ \\
Elements $\mathrm{i}$ and & (eij) \\
$\mathrm{j}$ (eij) & \\
\hline $\mathrm{V}$ & If $\mathrm{e}_{\mathrm{ij}}=1$ and $\mathrm{e}_{\mathrm{ij}}=0$ \\
$\mathrm{~A}$ & If $\mathrm{e}_{\mathrm{ij}}=0$ ang $\mathrm{e}_{\mathrm{ij}}-1$ \\
$\mathrm{X}$ & If $\mathrm{e}_{\mathrm{ij}}=1$ and $\mathrm{e}_{\mathrm{ij}}=1$ \\
$\mathrm{O}$ & If $\mathrm{e}_{\mathrm{ij}}=0$ and $\mathrm{e}_{\mathrm{ij}}=0$ \\
\hline
\end{tabular}

Determination of respondents as experts based on: 1) reputation, position, and appropriate credibility on the topic of study; 2) have a minimum of 15 years experiences in the field of study; 3) willing to be interviewed in depth. Based on these criteria, experts / speakers were selected, namely researchers from the Ministry of Energy and Mineral Resources, Researchers at the Ministry of Environment and Forestry, landscape http://ojs.unud.ac.id/index.php/eot management researchers, ecotourism researchers, ecotourism economic researchers, and forestry social researchers with specifications on landscape architecture, forestry, mining and ecotourism. Determination of subelements is carried out through Focus Group Discussion (FGD) of stakeholders involved in management of the area until a compromise is reached (Table 2).

\section{Data Processing}

Processing data using ISM with the ISM-VAXO method with the following steps:

(1)Preparation of the SSIM matrix In modeling with ISM opinion or assessment of contextual relations elements expressed in the form of letters $\mathrm{V}, \mathrm{A}, \mathrm{X}, \mathrm{O}$ which indicate that:

$\mathrm{V}$ : the $\mathrm{i}^{\text {th }}$ sub element has a relationship with the $\mathrm{j}^{\text {th }}$ sub element and the $\mathrm{j}^{\text {th }}$ sub element does not have a relationship with the $i^{\text {th }}$ sub element

A: the jth sub element has a relationship with the $i^{\text {th }}$ sub element and the $\mathrm{i}^{\text {th }}$ sub element does not have a relationship with the $\mathrm{j}^{\text {th }}$ sub element

$X$ : the $i^{\text {th }}$ sub element has a reciprocal relationship with the $\mathrm{j}^{\text {th }}$ sub element

$O$ : the $i^{\text {th }}$ sub element does not have 285 e-ISSN: 2407-392X. p-ISSN: 2541-0857 
a reciprocal relationship with the $\mathrm{j}^{\text {th }}$ sub element

Table 2. Elements of an ecotourism development system

\begin{tabular}{|c|c|}
\hline $\begin{array}{c}\text { The } \\
\text { Elements }\end{array}$ & SS \\
\hline $\begin{array}{l}\text { The } \\
\text { objectives }\end{array}$ & $\begin{array}{l}\text { One sub-element of } \\
\text { purpose contributes to } \\
\text { the achievement of sub- } \\
\text { elements of the other } \\
\text { objectives }\end{array}$ \\
\hline $\begin{array}{l}\text { The } \\
\text { needs }\end{array}$ & $\begin{array}{l}\text { One sub element of } \\
\text { needs supports the } \\
\text { fulfillment of sub } \\
\text { elements of the other } \\
\text { needs }\end{array}$ \\
\hline $\begin{array}{l}\text { The } \\
\text { obstacles }\end{array}$ & $\begin{array}{l}\text { One sub element of the } \\
\text { constraint causes another } \\
\text { sub element of the } \\
\text { constraint }\end{array}$ \\
\hline $\begin{array}{l}\text { The } \\
\text { activitie }\end{array}$ & $\begin{array}{l}\text { One sub-element of } \\
\text { development activities } \\
\text { supports the other sub- } \\
\text { elements of activity }\end{array}$ \\
\hline $\begin{array}{l}\text { The } \\
\text { actors }\end{array}$ & $\begin{array}{l}\text { Sub elements of one } \\
\text { actor in development } \\
\text { need to be supported by } \\
\text { other sub-elements of } \\
\text { actors }\end{array}$ \\
\hline
\end{tabular}

(2) Transformation of SSIM matrix into

Reachability matrix (RM)

The contextual relationship between sub-elements in the matrix form whose cells are in the form of letters (VAXO) is transformed into a Reachability matrix of binary numbers.

(3)Testing and transforming the Reachability matrix

Reachability matrix if Boolean operation fulfills reflexive and transitive conditions, if not, then adjustments are made by performing recursive multiplication operations so that a causal looping condition is formed.

\section{Classification of sub elements}

The classification of sub elements is determined by the level of each sub element with the following rules:

(1)Create an RM matrix after going through the transitivity stage.

(2)Determine the level of each sub element by first determining reachability (horizontally for subelements worth 1).

(3)Of course antecedent (vertically for sub-elements worth 1).

(4)Determine intersection (same value).

(5)If the reachability and intersection values are the same, then the level of the sub elements can be determined.

(6)Eliminate sub-elements whose level is known.

(7)Repeat the procedure until all subelements can be determined by the level.

\section{RESULTS AND DISCUSSION}

\section{The Objectives in the Management of}

\section{Ecotourism Areas}

Based on the results obtained through the Focus Group Discussion e-ISSN: 2407-392X. p-ISSN: 2541-0857 
(FGD), there are several objectives to be achieved in managing this ecotourism area. The objectives achieved in developing ecotourism in the Salak Mountain II Resort Area, HSNP are: (1) development of tourist areas with the concept of ecotourism; (2) conservation of biological natural resources and their ecosystems; (3) utilization of natural resource potential; (4) protection of potential ecotourism objects; (5) protection of national vital objects; (6) provide education to the public about environmental management; (7) provide education to the public about the culture of the local community; (8) reducing the number and role of unlicensed local communities; (9) increasing the active role and independence of the community in ecotourism activities; (10) improve community welfare. Between one objective with another objective has a contextual relationship that there is a contribution of objectives to one another and the objective of one with other objectives to contribute to each other. On the other hand there is a goal between one and the other not contributing to each other.

Based on the ISM analysis conducted showing that the goal of developing ecotourism in the Salak Mountain II Resort Area, HSNP has the highest level of objectives, namely http://ojs.unud.ac.id/index.php/eot reducing the number and role of unlicensed local communities. At the lowest level, the objective is to conserve biological natural resources and their ecosystems and provide education to the community about environmental management (Figure 1). There are similar parallels from the goal of developing this ecotourism area at the middle level, namely the aim of protecting the potential of ecotourism objects, protecting national vital objects and increasing the active role and independence of the community in ecotourism activities. In addition, the aim is to educate the public about the culture of the local community and improve community welfare.

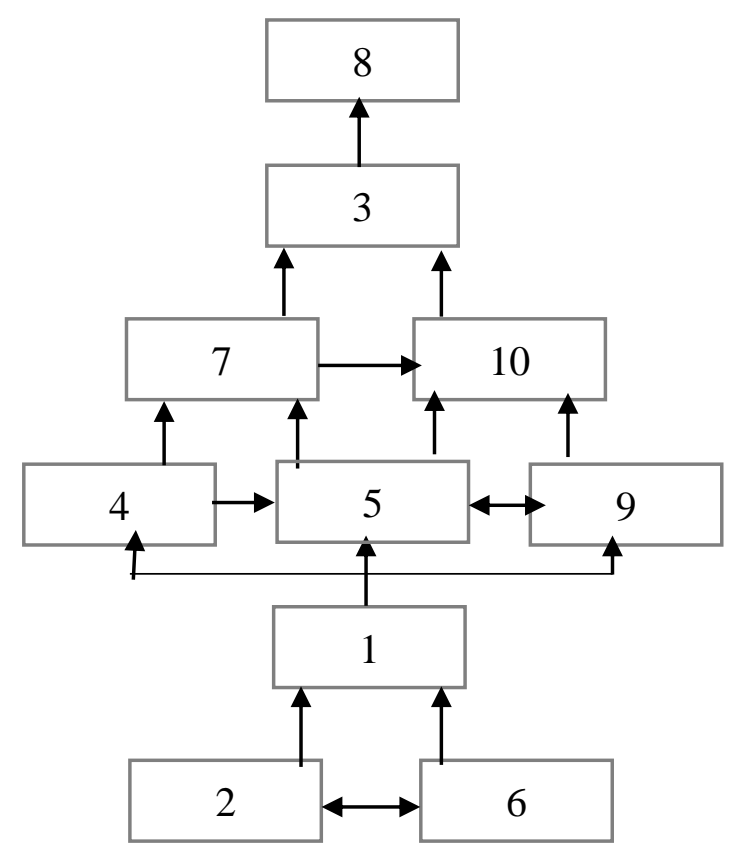

where :

1: development of tourist areas with the concept of ecotourism; 2: conservation of biological natural resources and their ecosystems; 3: utilization of natural resource potential; 4: protection of potential ecotourism objects; 5: protection of national vital objects; 
6: provide education to the community about environmental management; 7: provide education to the community about the culture of the local community; 8: reducing the number and role of unlicensed local communities; 9: increasing the active role and independence of the community in ecotourism activities; 10: improving people's welfare.

Figure 1. The hierarchical structure of the objectives of developing the Salak Mountain II Ecotourism Area, HSNP

Based on the graph in Figure 2 can be shown the strength as a driver power and the level of dependence. The 1st objective has strength as a strong driver power and has a dependency on a sufficient level. The 2 nd objective 2 has strength as a driver power that is very strong and has a dependency at a level that is strong enough. The 3rd objective has strength as a sufficient driver power but has a strong dependency. The 4th and the 5th objective have strength as a driver power that is strong enough and has a dependence on a sufficient level. The 6th objective has strength as a very strong driving factor but dependence is at a sufficient level. The 7 th and the 10th objective have strength as a strong enough driving factor and dependence on a sufficient level. The 8th objective has the strength as a low driver power and dependence on a sufficient level. The 9th objective has strength as a motivator that is strong enough but dependency is at a very strong level. The aim of the

ecotourism development area is the effort to increase the active role of the community and the independence of the community in ecotourism activities very much depending on the 1 st objective to the 8th objective. The objective of developing an ecotourism area is the effort to conserve natural resources and its ecosystem is a goal that has a very strong driving power but also needs strong support from other objectives. The objective of developing an ecotourism area is to provide education to the community about environmental management, a very strong driving power, but need to be supported by strong efforts from the 2nd objective and the $1 \mathrm{st}$ objective. The objective of developing an ecotourism area, namely the effort to reduce the number and role of unlicensed local communities, is an objective achievement that is supported by many other goals.

\section{The Needs That Required in Management of Ecotourism Areas}

Based on the results obtained through the FGD, there are some needs to be fulfilled in the management of this ecotourism area. The needs to be fulfilled in developing ecotourism in the Salak Mountain II Resort Area, HSNP are: (1) management institutions; (2) investors; (3) ecotourism master plan documents; (4) the 
legality of the ecotourism area; (5) improvement of accessibility to ecotourism areas; (6) enhancing the skills and capacity of human resources for ecotourism management; (7) facilities and infrastructure; (8) marketing; promotion; and (10) cultural attractions. Between one need and the other needs has a contextual relationship that there is a need that supports the fulfillment of other needs as well as the existence of one need with another need to support the fulfillment of needs. On the other hand, there is a need between one and the other needs that does not support each other.

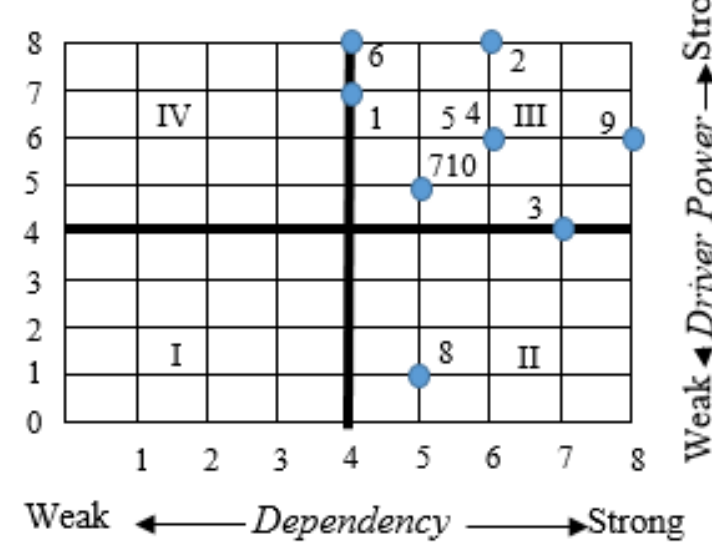

where :

I : autonomous barrier; II : dependent barrier; III : linkage barrier; IV : independent (driver) barrier

Figure 2. Graph of the driving factors and dependency factors of each of the objectives of developing the Salak Mountain II Resort Area, HSNP

Based on the ISM analysis conducted shows that the development of ecotourism in the Salak Mountain II http://ojs.unud.ac.id/index.php/eot
Resort Area, HSNP has the highest level of needs, namely the presence of investors. At the lowest level, the ecotourism area needs legality and the need for cultural attractions (Figure 3). There are equal parallels at the middle level, namely the need for a master plan document and the need for marketing. In addition to the need to improve accessibility, increase the skills and capacity of human resources for ecotourism management, and the existence of facilities and infrastructure.

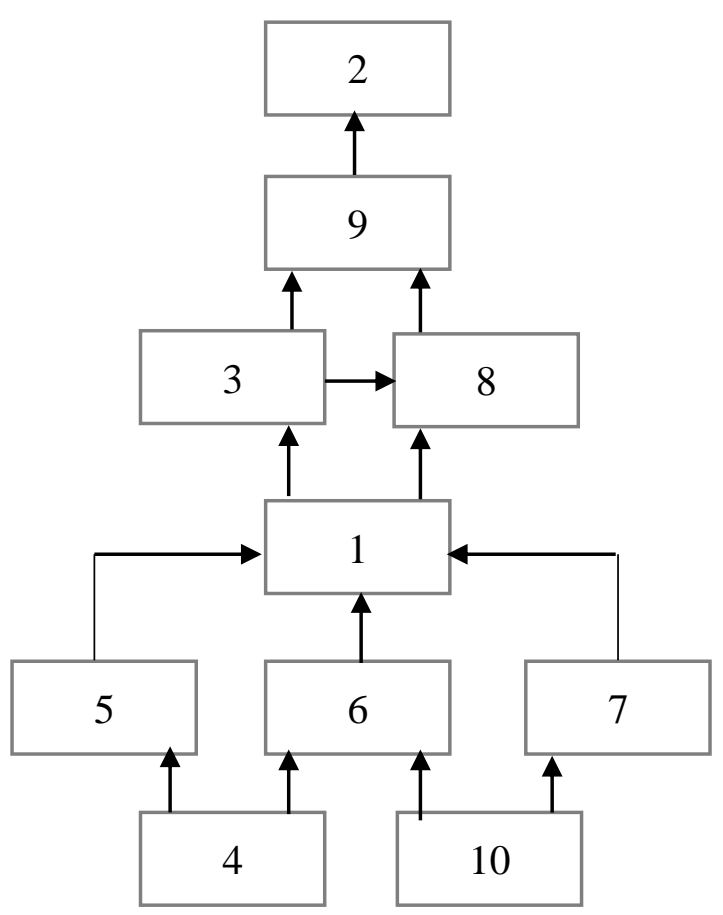

where :

1: management institutions; 2: investors; 3 : ecotourism master plan document; 4: the legality of the ecotourism area; 5: improvement of accessibility to ecotourism areas; 6: improving the skills and capacity of human resources for ecotourism management; 7: facilities and infrastructure; 8: marketing; 9: promotion; and 10: cultural attractions.

Figure 3. A hierarchical structure of the needs for developing an Ecotourism Area Salak Mountain II Resort, HSNP

e-ISSN: 2407-392X. p-ISSN: 2541-0857 
Based on ISM analysis, it shows that the need for the legality of ecotourism and cultural attractions has a very strong driving factor in the development of the Salak Mountain II Ecotourism area, HSNP. The need that is very dependent on other needs is the presence of investors, the existence of ecotourism master plan documents, the existence of marketing, and the existence of promotions. The need that has a fairly weak dependence on other needs is the existence of the legality of the ecotourism area, the existence of cultural attractions, the improvement of accessibility to ecotourism areas, an increase in skills and capacity of human resources for ecotourism management and the need for facilities and infrastructure (Figure 3). The existence of institutional management needs is a supportive need depending on other needs and enough to get encouragement from other needs, namely the third and eighth needs. This first need provides an impetus for achieving the fifth, sixth and seventh needs (Figure 4).

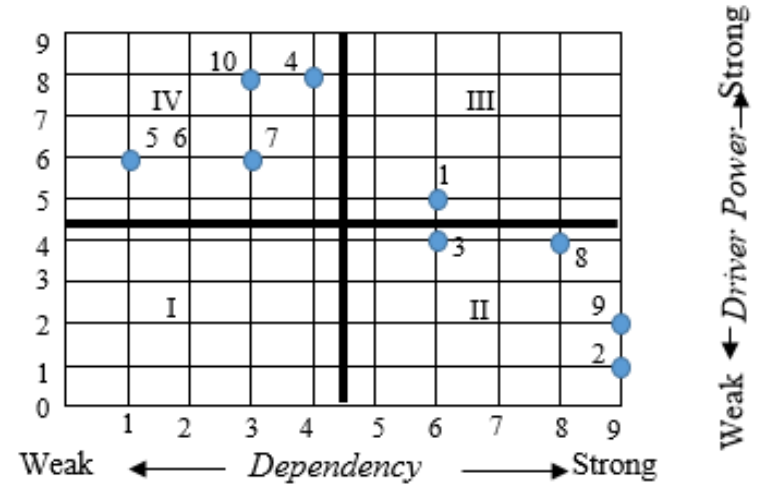

where :

I : autonomous barrier; II : dependent barrier; III : linkage barrier; IV : independent (driver) barrier

Figure 4. Graph of the driving factors and dependency factors of each of the needs for the development of the Salak Mountain II Resort Area, HSNP

\section{The Obstacles in the Management of}

\section{Ecotourism Areas}

Based on the results obtained through the FGD, several obstacles were found to be fulfilled in the management of this ecotourism area. Constraints in developing ecotourism in the Salak Mountain II Resort Area, HSNP are: (1) changes in the behavior of former forest encroachers to tourism businesses; (2) limited investors; (3) limited human resources who have knowledge, skills and professionalism in managing ecotourism; (4) inadequate facilities and infrastructure; (5) changes in the status from utilization zones to ecotourism zone; (6) there is no institution (BUMDES/others) that can manage this ecotourism area; (7) weak knowledge about the conservation of 
natural and environmental resources; (8) promotion; (9) marketing; (10) efforts in the utilization zone are still ongoing. Between one obstacle and another obstacle has a contextual relationship that the existence of one constraint causes more constraints and the constraints that one with other constraints cause each other. On the other hand there are obstacles between one and the other constraints that do not cause each other (Figure 5).

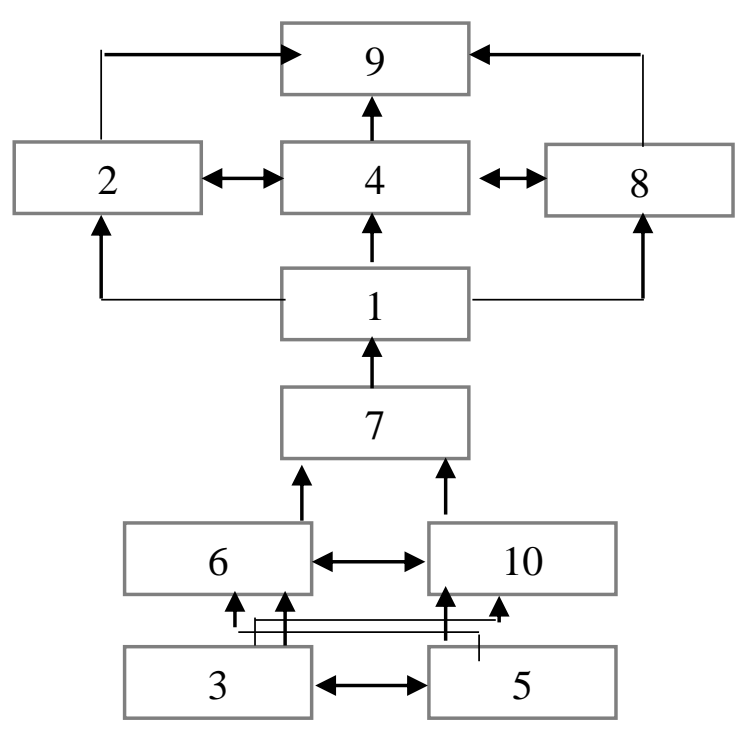

where :

1: changes in the behavior of former forest encroachers to tourism businesses; 2: limited investors; 3: limited human resources that have knowledge, skills and professionalism in managing ecotourism; 4: inadequate facilities and infrastructure; 5: changes in the status from utilization zones to ecotourism zones; 6 : there is no institution (BUMDES / other) that can manage this ecotourism area; 7: weak knowledge about the conservation of natural and environmental resources; 8: promotion; 9: marketing; 10: efforts in the utilization zone are still ongoing

Figure 5. The hierarchical structure of constraints in developing the Salak Mountain II Ecotourism Area, HSNP

http://ojs.unud.ac.id/index.php/eot
Based on the ISM analysis conducted shows that the development of ecotourism in the Salak Mountain II Resort Area, HSNP has the highest level of constraints, namely the problem of marketing. At the lowest level, there are constraints on the limited human resources that have the knowledge, skills and professionalism in ecotourism management as well as the constraints of changing the status of utilization zones from forest areas to ecotourism areas. There are similar parallels at the middle level, namely the constraints that there is no institution (BUMDES/others) that can manage this ecotourism area and the constraints of efforts in the utilization zone are still ongoing. In addition to the constraints of limited investors, inadequate facilities and infrastructure, and promotions.

Based on the results of the ISM analysis, it shows that there are obstacles that have a very strong dependency, namely marketing constraints. In addition there are constraints that have a strong dependence on the limited investor and promotion and inadequate facilities and infrastructure. There are several obstacles as a strong driver power but have a fairly weak dependency, namely the constraints of limited human resources that have knowledge, skills and professionalism as well as the constraints of changing the 
status from utilization zones into ecotourism zone. There are several obstacles as a strong enough driver power but has a strong enough dependency, namely the constraints of the existence of businesses in the utilization zone that are still ongoing and the lack of knowledge about the conservation of natural resources and the absence of institutions (BUMDES/others) that can manage ecotourism areas professional. The obstacle of the absence of changes in former forest encroachers to tourism businesses is an obstacle that has a dependency with other constraints that are quite strong and these constraints can also be quite strong drivers (Figure 6).
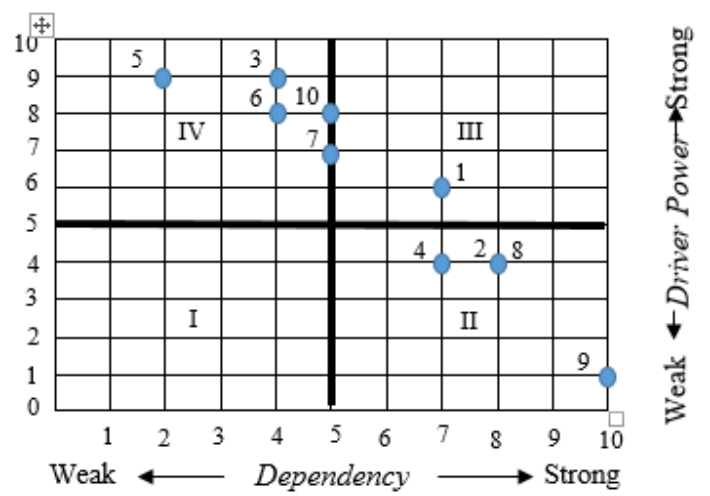

where :

I : autonomous barrier; II : dependent barrier; III : linkage barrier; IV : independent (driver) barrier

Figure 6. Graph of the driving factors and dependency factors of each obstacle to the development of the Salak Mountain II Resort Area, HSNP

\section{The Desired Ecotourism Activities}

Based on the results obtained through the FGD, there are some activities that can be done in managing this ecotourism area. Activities in developing ecotourism in the Salak Mountain II Resort Area, HSNP namely: (1) agro tourism; (2) local cultural and artistic attractions; (3) ecotourism; (4) natural recreation; (5) home stay lodging; (6) sales of souvenirs, natural and cultural products. Between one activity and another activity has a contextual relationship that the existence of one activity supports other activities and the existence of activities with one another supports each other. On the other hand there are activities between one and the other activities that do not support each other (Figure 7).

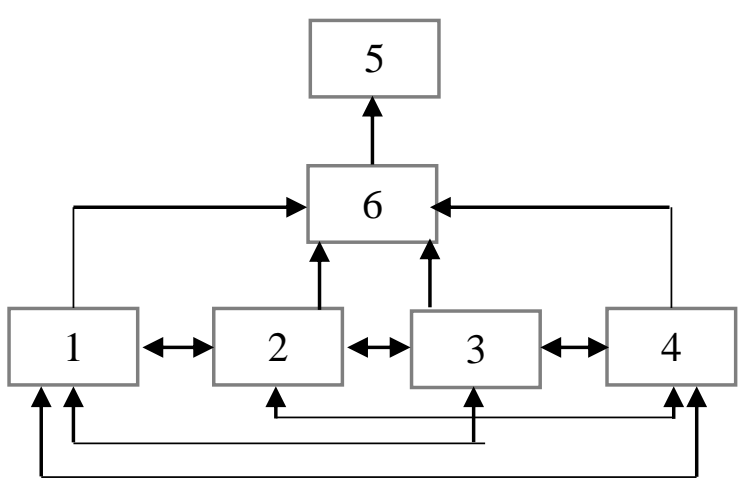

where :

1 : agrotourism; 2 : local cultural and artistic attractions; 3 : ecotourism; 4: natural recreation; $5:$ home stay; 6 : sales of souvenirs, natural and cultural products.

Figure 7. The hierarchical structure of the development activities of the Salak Mountain II Ecotourism Area, HSNP 
Based on the ISM analysis conducted shows that the development of ecotourism in the Gunung Salak II Resort Area, GHSNP has the desire to develop activities at the highest level namely home stay. At the lowest level has the desire to develop agro-tourism activities; 2: local cultural and artistic attractions; 3: ecotourism; 4: natural recreation. At the middle level, it wants the activities of selling souvenirs, natural and cultural products.

Based on the results of the ISM analysis shows that there are home stay activities and souvenir sales activities, natural and cultural products are activities that are quite dependent but low as a driver of other activities. Agro-tourism activities, local cultural and artistic attractions, ecotourism, and natural recreation are activities that are very powerful drivers but are activities that also have enough dependency (Figure 8).

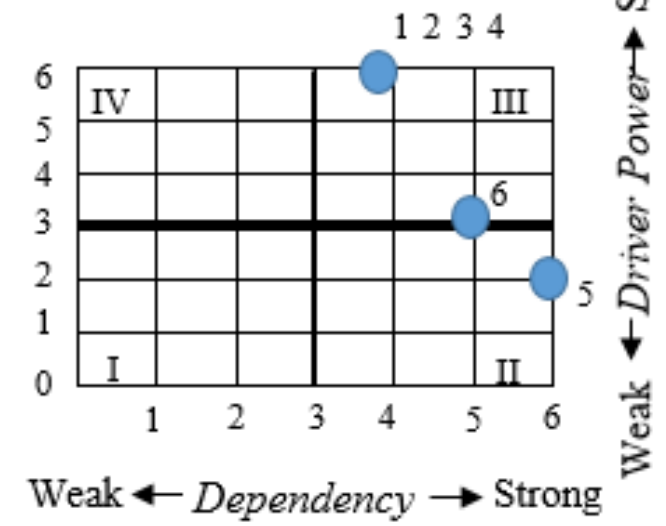

where :

I : autonomous barrier; II : dependent barrier; III : linkage barrier; IV : independent (driver) barrier

Figure 8. Graph of the driving factors and dependency factors of each activity in the development of the Salak Mountain II Resort Area, HSNP

The Actors in the Management of Ecotourism Areas

Based on the results obtained through the FGD, there are some activities that can be done in managing this ecotourism area. Activities in developing ecotourism in the Salak Mountain II Resort Area, HSNP are: (1) Regional Planning, Development, and Research Agency of Bogor Regency Regional Government; (2) Tourism and Culture Office of Bogor Regency Regional Government; (3) Environmental Office of Bogor Regency Regional Goverment; (4) Regional Asset and Financial Institutions; (5) Salak Mountain II Resort Office, 
HSNP; (6) Khalifah Cooperative Agency;

(7) Higher Education Institutions; (8) Village-Owned Enterprises (BUMDES);

(9) Ministry of Environment and Forestry; (10) Ministry of Energy and Mineral Resources; (11) Regional Leadership Consultative Forum and District Leadership Consultative Forum; (12) Community Leaders; (13) NonGovernmental Organizations (NGOs); (14) Youth Organization; (15) Ex-Volunteer; (16) Investors; and (17) Halimun Salak National Park Office (BTNGHS). Between one activity and another activity has a contextual relationship that one actor needs to get the support of other actors and the actors who support one another. On the other hand there are actors one with other actors who do not support each other (Figure 9).

Based on the ISM analysis conducted shows that the development of ecotourism in the Salak Mountain II Resort Area, HSNP has actors in developing activities at the highest level, namely ex-volunteers. At the lowest level, they have actors in developing activities, namely the Regional Asset and Financial Institutions, Salak Mountain II Resort
Office, HSNP, Khalifah Cooperation Agency, Village-Owned Enterprises (BUMDES), community leaders, NonGovernmental Organizations (NGOs), youth organizations, and investors . At the middle level, they have actors in developing activities namely Higher Education Institutions, Ministry of Energy and Mineral Resources, Halimun Salak National Park Office (HSNPO), Ministry of Environment and Forestry, Regional Leadership Consultative Forum and District Leadership Consultative Forum, Tourism and Culture Office of Bogor Regency Regional Government, Regional Planning, Development, and Research Agency of Bogor Regency Regional Government, and Environmental Office of Bogor Regency Regional Goverment. Four actors at the same level, namely the Ministry of Energy and Mineral Resources, and the Halimun Salak National Park Office (HSNPO)) and the Ministry of Environment and Forestry, Regional Leadership Consultative Forum and District Leadership Consultative Forum. 


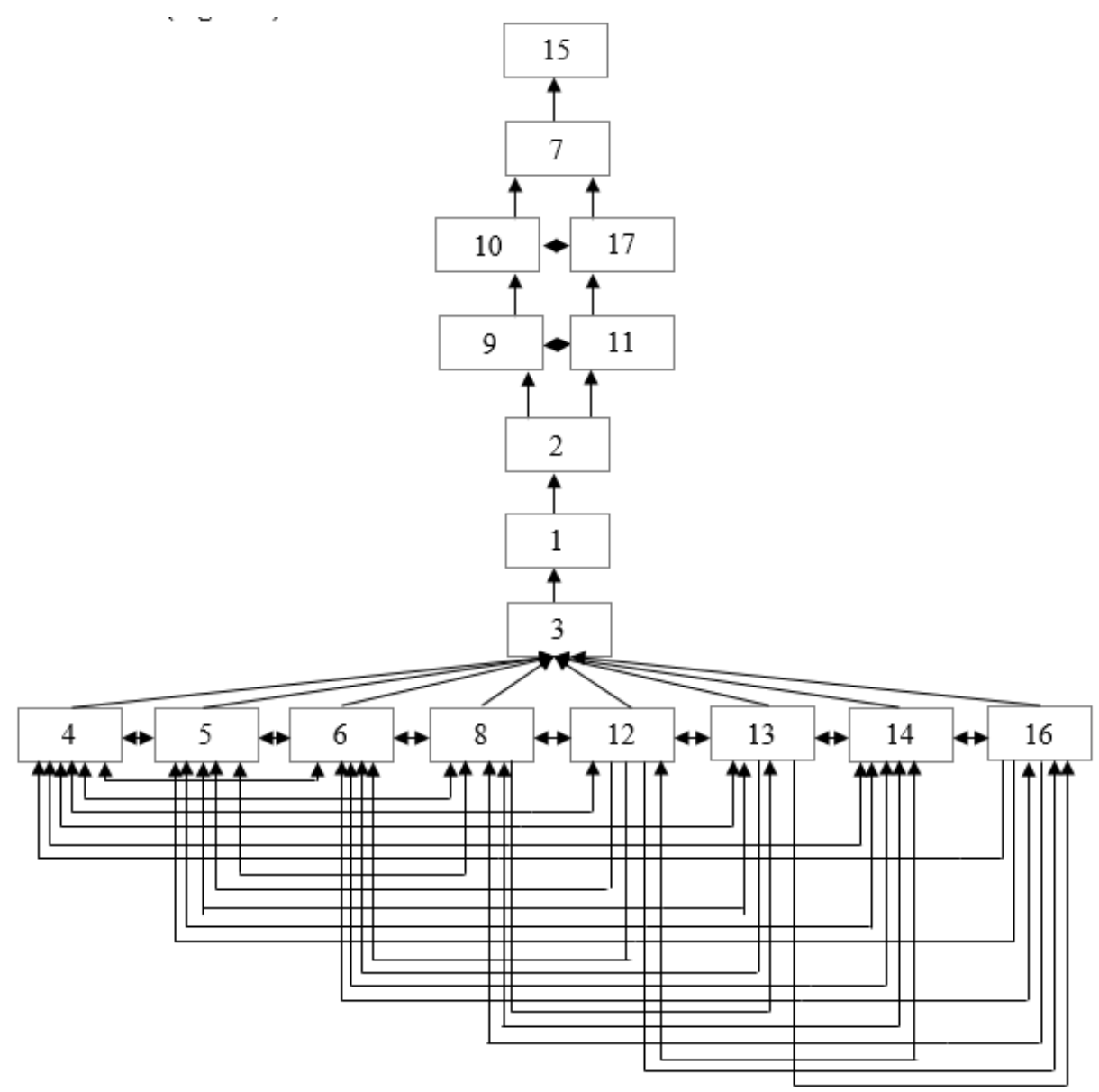

where :

1 : Regional Planning, Development, and Research Agency of Bogor Regency Regional Government; 2 : Tourism and Culture Office of Bogor Regency Regional Government; 3 : Environmental Office of Bogor Regency Regional Goverment; 4 : Regional Asset and Financial Institutions; 5 : Salak Mountain II Resort Office, HSNP; 6 : Khalifah Cooperative Agency; 7 : Higher Education Institutions; 8 : Village-Owned Enterprises (BUMDES); 9 : Ministry of Environment and Forestry; 10 : Ministry of Energy and Mineral Resources; 11 : Regional Leadership Consultative Forum and District Leadership Consultative Forum; 12 : Community Leaders; 13 : Non-Governmental Organizations (NGOs); 14 : Youth Organization; 15 : Ex-Volunteer; 16 : Investors; and 17 : Halimun Salak National Park Office (HSNPO).

Figure 9. Structure of the hierarchy of actors in the development of the Salak Mountain II Resort Area, HSNP

There are 8 ecotourism management actors who must support each other based on expert perceptions, namely the Regional Asset and Financial Institutions, Salak Mountain II Resort Office, HSNP, Khalifah Cooperation Agency, Village-Owned Enterprises (BUMDES), community leaders, NonGovernmental Organizations (NGOs), http://ojs.unud.ac.id/index.php/eot eight actors received support from the Environmental Office of Bogor Regency Regional Goverment, where this service needs to be supported by the Regional Planning, Development, and Research Agency of Bogor Regency Regional Government and Tourism and Culture Office of Bogor Regency Regional e-ISSN: 2407-392X. p-ISSN: 2541-0857 
Government. The abovementioned actors need to get support from the Ministry of Environment and Forestry and Regional Leadership Consultative Forum and District Leadership Consultative Forum, where the two actors support each other in managing the ecotourism area. The Halimun Salak National Park Office (HSNPO) and the Ministry of Energy and Mineral Resources support each of the above mentioned actors. Higher Education Institutions are institutions that have the ability in the fields of education, research and community service to provide support to the above actors as an effort to run good management in the protection of natural resources as well as ecotourism. Ex-volunteers as freelancers in ecotourism management coordinated by the Salak Mountain II Resort Office, HSNP have a role in supporting all actors involved in managing ecotourism (Figure 9).

The actors from community leaders, community institutions, youth organizations, and investors are lowdependency actors to other actors. Actors of Higher Education Institutions, Ministry of Energy and Mineral Resources have a very high dependence on other actors. HSNPO has a medium dependency on other actors. The actors of Regional Finance and Asset Agencies, Salak Mountain II Resort Offices, HSNP, Khalifah Cooperative Agency and http://ojs.unud.ac.id/index.php/eot
Village-Owned Enterprises (BUMDES) have driving forces for ecotourism management but have sufficient interest in other actors. The actors of the Ministry of Environment and Regional Leadership Consultative Forum and District Leadership Consultative Forum have dependence on other actors who are quite strong. Regional Planning, Development, and Research Agency of Bogor Regency Regional Government actors, Tourism and Culture Office of Bogor Regency Regional Government and the Environmental Office of Bogor Regency Regional Goverment are actors who have sufficient driving forces who also have sufficient dependence on other actors (Figure 10).

\section{The Model of Salak Mountain II Resort Ecotourism Management, HSNP}

Management of the Salak Mountain II Resort Area, HSNP towards co-tourism management in an effort to support the sustainability of the area as a conservation area for natural resources and its ecosystem. The seventeen actors as stated above have contributions that are in accordance with their respective objectives with the principle of sustainable protection and development of the Salak Mountain II Resort Ecotourism Area, HSNP. There are several needs that 
are felt important for the implementation of the development of this region as a sustainable ecotourism area. Each actor in collaborating together in meeting needs and overcoming obstacles. The CoTourism Management as proposed does not take over the role of the Salak Mountain II Resort Office, HSNP, HSNPO and the Ministry of Environment and Forestry in managing the area. CoTourism Management in question is a joint management effort in carrying out an activity program in the area, efforts to protect the area and efforts to manage the area so that the area can be characterized, sustainable, safe and comfortable in the utilization of limited activities.

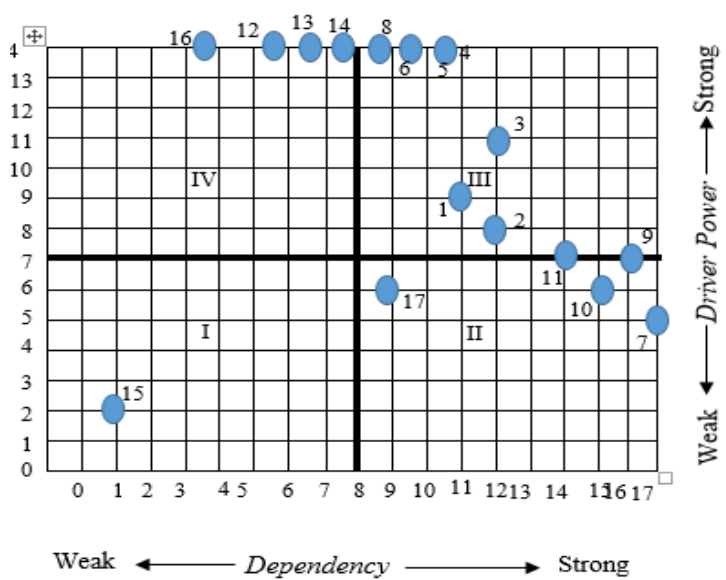

where :

I : autonomous barrier; II : dependent barrier; III : linkage barrier; IV : independent (driver) barrier

Figure 10. Graph of the driving factors and dependency factors of each actor in the development of the Salak Mountain II Resort Area, HSNP

http://ojs.unud.ac.id/index.php/eot
In managing the area there are 5 (five) dependents who are strong enough to be very strong. The five actors are The Higher Education Institutions, The Ministry of Environment and Forestry, the Ministry of Energy and Mineral Resources, Regional Leadership Consultative Forum and District Leadership Consultative Forum, and HSNPO. Based on Figure 9, higher education institutions support the other four actors above.

Four actors who have the power as a driver that has a low dependence on other actors, namely investors, community leaders, non-governmental organizations, and youth organizations. To develop ecotourism activities, community leaders and non-governmental organizations need support from investors. On the other hand, there is mutual support between community leaders and non-governmental organizations, between non-governmental organizations and youth organizations, between youth organizations and investors, and between community leaders and youth organizations.

Regional Planning, Development, and Research Agency of Bogor Regency Regional Government, Tourism and Culture Office of Bogor Regency Regional Government, and Environmental Office of Bogor Regency Regional Goverment have strong enough driving 
factors and are a liaison between actors who lack dependency with other actors and actors who are highly dependent on other actors. There are 4 actors who have very strong driving factors, namely the Regional Financial and Asset Institutions, Salak Mountain II Resort Office, HSNP, Khalifah Cooperative Agency, and Village-Owned Enterprises. The four actors are the liaison between actors who lack dependency with other actors and actors who are highly dependent on other actors. In general, the hierarchy structure model of Salak Mountain II Resort Office Ecotourism Management Organization, HSNP can be seen in Figure 11.

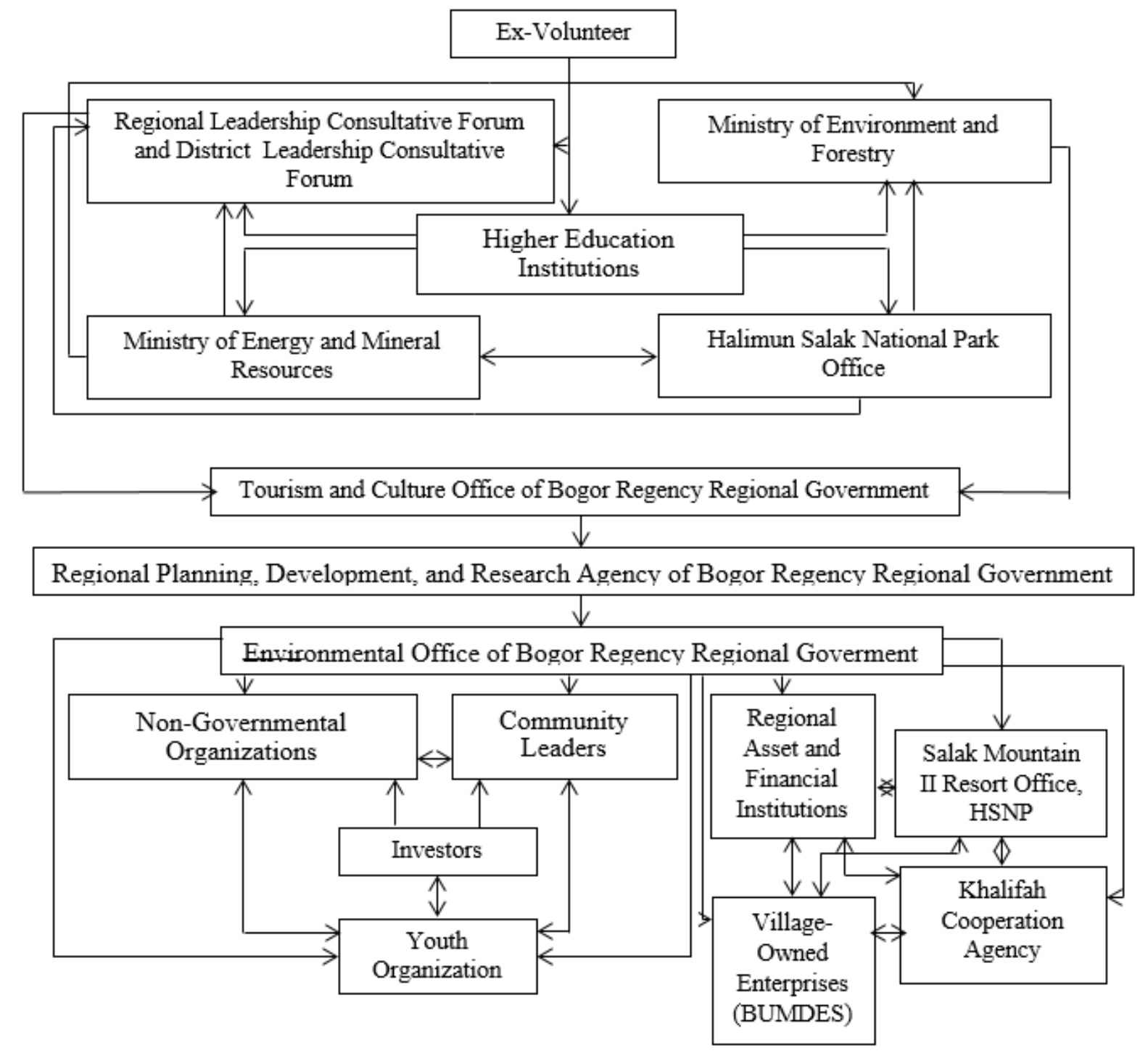

where :

$\longrightarrow$ : Providing support

$\longleftrightarrow$ : Mutual support

Figure 11. Model of Salak Mountain II Resort Office Ecotourism Management, HSNP 
Based on the diagram in Figure 11, providing support and mutual support among the actors is an effort to achieve the objectives of developing and managing the Gunung Salak Mountain II Ecotourism Area, HSNP as stated in Figure 1. In addition, the actors also provide mutual support in an effort to meet the needs that needed for managing ecotourism. To run the activities program in this area which is managed based on togetherness, several constraints are solved jointly to realize a sustainable ecotourism area.

Higher education institutions have a role in supporting institutions at the central level (HNSPO, The Ministry of Environment and Forestry, the Ministry of Energy and Mineral Resources) and regional leaders' deliberations in providing policies, directives and legislation in the management of ecotourism areas that will be used by institutions in the region : Tourism and Culture Office of Bogor Regency Regional Government, Regional Planning, Development, and Research Agency of Bogor Regency Regional Government, and Environmental Office of Bogor Regency Regional Goverment. Higher Education Institutions have the role of providing support in the fields of education, research, and community service that can be used by institutions in http://ojs.unud.ac.id/index.php/eot the region to provide direction and policies to local institutions in the region, namely the Salak Mountain II Resort Office, HSNP and the Kalifah Cooperative Agency. The directives and policies based on studies of education, research and community service are also needed by community groups. The Khalifah Cooperative Agency which was formed as an institution that can collaborate with the Salak Mountain II Resort Office, HSNP supports community leaders and non-governmental organizations in carrying out joint activities to realize the sustainable Salak Mountain II Resort Ecotourism Area, HSNP. In addition, the Khalifah Cooperative Agency can work together (support each other) with youth Youth Organization and investors.

\section{CONCLUSION}

The Salak Mountain II Resort Ecotourism Area, HSNP is an area that has very interesting ecotourism objects. This condition requires good management towards a sustainable ecotourism area. The results of the focus group discussion (fgd) show that there are goals, constraints, needs and program activities in the development and management of the ecotourism area. In addition to providing 
good management, cooperation between actors is needed in the form of CoTourism Management.

The main goal in the development and management of the Salak Mountain II Resort Ecotourism Area, HSNP is the conservation of biological natural resources and their ecosystems and providing education to the public about environmental management. These two goals are the drivers of other very strong goals. The objectives to be achieved are also aimed at reducing the number of unlicensed area management communities.

Based on the results of fgd, the legality of ecotourism areas and cultural attractions is needed. Cultural attractions are activities that are rarely carried out in this region. Both of these needs are strong drivers for other needs. Other needs namely improving accessibility to ecotourism areas; improving human resource skills and capacity for ecotourism management; and facilities and infrastructures are needs that are also powerful enough drivers for other needs.

Based on the results of the fgd, there are several constraints as a strong driver for other constraints, namely the limited human resources that have the knowledge, skills and professionals in managing ecotourism as well as changing the status from utilization zone to the ecotourism zone. Marketing activities are http://ojs.unud.ac.id/index.php/eot obstacles that are very dependent on other constraints.

Based on the results of fgd, there is an activity program that can be developed and managed in this ecotourism area, namely agro-tourism; local cultural and artistic attractions; ecotourism; nature recreation. These four activities are very powerful drivers and have links between one activity and other activities. Home stay lodging and souvenir sales, natural and cultural products are highly dependent on other activities

Based on the results of the fgd, there are actors of community leaders, non-governmental organizations, youth organizations, and investors who have very strong and not dependent motivating factors on other actors. The three actors who have a strong motivating factor and are the liaison between actors who do not depend on other actors with actors who depend on other actors namely Regional Planning, Development, and Research Agency of Bogor Regency Regional Government, Tourism and Culture Office of Bogor Regency Regional Government, and Environmental Office of Bogor Regency Regional Goverment. There are four actors who have very strong dependence on other actors namely the Higher Education Institution, the Ministry of Environment and Forestry, the Ministry of Energy and Mineral Resources, and the 
Regional Leadership Consultative Forum and District Leadership Consultative Forum.

In this ecotourism management model, Higher Education Institutions have a role in supporting institutions at the central level (HSNPO, the Ministry of Environment and Forestry, the Ministry of Energy and Mineral Resources) and regional leaders' deliberations in providing policies, directives and legislation in the management of ecotourism areas that will be used by institutions in the region namely Tourism and Culture Office of Bogor Regency Regional Government, Regional Planning, Development, and Research Agency of Bogor Regency Regional Government, and the Environmental Office of Bogor Regency Regional Goverment. Higher Education Institutions have the role of providing support in the fields of education, research, and community service that can be used by institutions in the region to provide direction and policies to local institutions in the region, namely the Salak Mountain II Resort Office, GHSNP and the Khalifah Cooperative Agency.

\section{ACKNOWLEDGEMENT}

The researcher thanked to the BNOPT Ministry of Research and Higher Education for the cost of this applied http://ojs.unud.ac.id/index.php/eot research. The researcher also thanked to the Salak Mountain II Resort Office, HNSP and HNSPO for giving the opportunity to researchers to take research locations in the Salak Mountain II Resort Area, HNSP. The researcher also thanked to the Bogor Agricultural Institute Library for providing the opportunity so that researchers could conduct library searches.

\section{REFERENCES}

Avenzora R. (2008) Ekoturisme : Evaluasi Tentang Konsep. Avenzora R, editor. NAD-Nias (ID): BRR NAD-Nias.

Buchsbaum B.D. (2004) Ecotourism and Sustainable Development in Costa Rica. Virginia Polytechnic and State University. USA.

Choy D.L. (1997) Perencanaan Ekowisata, Belajar dari Pengalaman di South East Queensland. Proceding in the Training and Workshop of Planning Sustainable Tourism. Bandung (ID): Penerbit ITB.

Dunn W. (1988) Methods of The Second Type : Coping with The Wildernessof Conventional Policy Analysis. Policy Studies Review, 7:720-737.

Ernawati A and Kusumoarto A. (2018) The Ecodesign Concept for Kondang Waterfall Ecotourism Object in Salak II Resort Area, The Halimun-Salak National Park. Sch. J. Arts Humanit. Soc. Sci. 6(5): 994-1020. doi : 10.21276/sjahss.2018.

Eriyatno and Sofyan F. (2007) Riset Kebijakan Metodologi Penelitian Untuk Pasca Sarjana. Bogor (ID): Institut Pertanian Bogor Press.

e-ISSN: 2407-392X. p-ISSN: 2541-0857 
Fandelli C. (2000) Perencanaan Kepariwisataan Alam. Dalam Fandelli $\mathrm{C}$ dan Muchlisin (Editor). Pengusahaan Ekowisata. Fakultas Kehutanan, Universitas Gajah Mada. Yogyakarta, 157-167 hal.

Gunn CA. (1994) Tourism Planning : Basics, Concepts, and Cases. Third Edition. London (UK): Taylor \& Francis Ltd.

Jubei S, Kusumoarto A, and Ernawati A. (2017) Analisis Trend Pengunjung Obyek Ekowisata di Kawasan Resor Gunung Salak II, Taman Nasional Gunung Halimun Salak. Temu Ilmiah Ke VI. Ikatan Peneliti Lingkungan Binaan Indonesia. Universitas Malikussaleh. Nanggroe Aceh Darussalam.

Machfud. (2001) Rekayasa Model Penunjang Keputusan Kelompok dengan Fuzzy Logic untuk Sistem Pengembangan Agroindustri Minyak Atsiri. [Disertasi]. Bogor (ID): Institut Pertanian Bogor.

Kusumoarto A and Ramadhan R (2016) Ecotourism and Suitability Evaluation of the Mount Salak Resort II in the Halimun-Salak National Park. In Radzi et al. (ed). Heritage, Culture and Society (London: Taylor \& Francis Group (pp 831).

Kusumoarto A, Gunawan A, Machfud, and Hikmat A. (2017) Landscape Character of Pongkor Mining Ecotourism Area. 2nd International Symposium for Sustainable Landscape Development. doi :10.1088/17551315/91/1/012028.

Kusumoarto A, Gunawan A, and Nurazizah G.R. (2017) Landscape Potential Analysis for Ecotourism Destination in the Resort Ii Salak Mountain, HalimunSalak National Park. 2nd International Symposium for Sustainable Landscape Development. doi :10.1088/17551315/91/1/012029.
Kusumoarto A and Ernawati A. (2017) Ecological Carrying Capacity Analysis of Ecotourism Objects In Salak II Resort Area, Halimun Salak National Park. Harmony with Nature Strengthening Relationships between Human and Environment. 1st International Geography Seminar. Univeritas Pendidikan Indonesia. Bandung. doi : 10.1088/17551315/145/1/012098

Porteous J.D. (1977) Environmental and Behavioral : Planning and Everyday Urban Life. Massachusetts (UK): Addison-Wesley Publ.Co.

Storey J. (1999) Changing Employment Practices in UK Banking : Case Studies. Personal Review Select 2, 3: 129-139. 